\title{
What do school teachers know about asthma?
}

\author{
M Bevis, B Taylor
}

\begin{abstract}
The results of a survey of 98 primary school teachers in inner London showed that they had only limited understanding of asthma and its management. Few teachers had received any teaching or training about the condition; the arrangements for giving antiasthmatic drugs were generally unsatisfactory and caused unnecessary disruption to the child's school life as well as preventing effective treatment. Training in the nature and treatment of common diseases like asthma should be made available for groups such as schoolteachers who are responsible for children so that optimal health care is ensured.
\end{abstract}

Asthma is the most common chronic disorder of childhood. ${ }^{1}$ It regularly causes absence from school being responsible for up to a third of the school absences that are the result of chronic diseases. ${ }^{2}$ Teachers are primarily responsible for supervising schoolchildren with asthma during school hours, ${ }^{34}$ and they make decisions regarding physical activities and both emergency and regular drug treatment. Few school teachers, however, receive instruction about asthma or how to manage asthmatic children. ${ }^{3}$

In this study we report a survey of primary schools in the Paddington area of London that was designed to assess the knowledge of asthma among primary schoolteachers, to identify particular areas of limited understanding, and to investigate how teachers feel about managing asthmatic children in school, together with the policies for giving treatment.

\section{Subjects and methods}

Eight schools in Paddington and north Kensington were entered into the study with the approval of the headteachers. Four further schools were approached but the headteachers declined to participate.

\section{Table 1 General knowledge of 98 teachers about asthma}

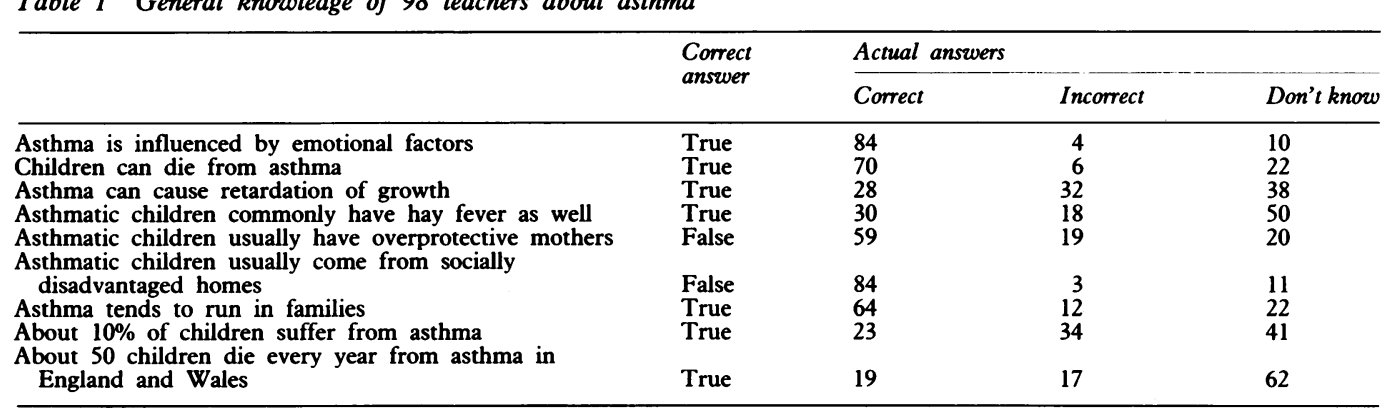

Ninety eight of a total of 122 teachers completed a precoded questionnaire during a lunch hour after a brief explanation of the aims of the study. Twenty teachers (mostly part time) were either absent or unavailable at the time of the visit, and four refused to participate.

The questionnaire comprised 38 statements about the nature of asthma that the respondent marked either true, false, or don't know. There were 17 additional questions about the teachers' views and opinions on asthmatic children, about their experience of children with asthma, and about their views on policy for giving medication.

The true and false answers were assigned as either correct or incorrect in the opinion of the investigators in consultation with other paediatric colleagues. The data was analysed, using the Statistical Package for the Social Sciences X (SPSSX) to provide tabulations and $\chi^{2}$ calculations.

Totals in the tables may not add up to $100 \%$ reflecting occasional missing data.

\section{Results}

Table 1 shows the response of teachers to a series of general statements about asthma. The number of correct responses varied from 19\% concerning the annual mortality rate, to $86 \%$ who were aware that emotions can influence asthma.

Table 2 shows their understanding of the relationship between asthma and sport. Nearly two thirds of teachers were aware that swimming is the best sport for asthmatic children, and $79 \%$ thought that asthmatic children should be encouraged to participate fully in games at school. Only 33\%, however, knew that premedication before games should prevent asthma; $47 \%$ of respondents were unsure.

Table 3 shows the responses of the teachers to statements about medication; it is clear that teachers' understanding was limited, most of them answering 'don't know' to all statements
St Mary's Hospital Medical School, London M Bevis

Royal Free Hospital School of Medicine, London

B Taylor

Correspondence to: Professor B Taylor Department of Community Child Health Royal Free Hospital, Pond Street, London NW3 2OG.

Accepted 2 February 1990 
Table 2 Knowledge of 98 teachers about asthma and sport

\begin{tabular}{|c|c|c|c|c|}
\hline & \multirow{2}{*}{$\begin{array}{l}\text { Correct } \\
\text { answer }\end{array}$} & \multicolumn{3}{|c|}{ Actual answers } \\
\hline & & Correct & Incorrect & Don't know \\
\hline \multirow{8}{*}{$\begin{array}{l}\text { Swimming is best sport } \\
\text { Full participation in games should be encouraged } \\
\text { Teachers should ensure that necessary drugs are taken } \\
\text { before games } \\
\text { Taking drugs before games should prevent an asthmatic } \\
\text { attack } \\
\text { Playing games in the rain increases the likelihood of an } \\
\text { attack } \\
\text { Playing games in a cold wind increases the likelihood } \\
\text { of an attack } \\
\text { Wheezing after exercise suggests asthma } \\
\text { Generally less competent at physical sports }\end{array}$} & True & 62 & 3 & 33 \\
\hline & True & 77 & 6 & 15 \\
\hline & True & 52 & 17 & 29 \\
\hline & True & 32 & 20 & 46 \\
\hline & False & 37 & 12 & 49 \\
\hline & False & 26 & 21 & 51 \\
\hline & True & 33 & 32 & 33 \\
\hline & False & 51 & 14 & 32 \\
\hline
\end{tabular}

Table 3 Understanding of 98 teachers about treatment of childhood asthma

\begin{tabular}{|c|c|c|c|c|}
\hline & \multirow{2}{*}{$\begin{array}{l}\text { Correct } \\
\text { answer }\end{array}$} & \multicolumn{3}{|c|}{ Actual answers } \\
\hline & & Correct & Incorrect & Don't know \\
\hline $\begin{array}{l}\text { Antibiotics are useful in treating asthma } \\
\text { Ventolin is a drug that opens the airways } \\
\text { Ventolin is effective immediately } \\
\text { Intal and Becotide work when a child is wheezy } \\
\text { Intal and Becotide fight chest infections } \\
\text { Ventolin can cause heart rate to rise } \\
\text { Ventolin can cause hands to tremble } \\
\text { Ventolin helps fight chest infections }\end{array}$ & $\begin{array}{l}\text { False } \\
\text { True } \\
\text { True } \\
\text { False } \\
\text { False } \\
\text { True } \\
\text { True } \\
\text { False }\end{array}$ & $\begin{array}{r}31 \\
60 \\
38 \\
3 \\
13 \\
14 \\
8 \\
26\end{array}$ & $\begin{array}{r}14 \\
0 \\
7 \\
17 \\
3 \\
6 \\
11 \\
4\end{array}$ & $\begin{array}{l}53 \\
38 \\
53 \\
78 \\
82 \\
78 \\
79 \\
68\end{array}$ \\
\hline $\begin{array}{l}\text { Medicines that should be used regularly are*: } \\
\text { Ventolin } \\
\text { Becotide } \\
\text { Intal } \\
\text { Bricanyl }\end{array}$ & $\begin{array}{l}\text { False } \\
\text { True } \\
\text { True } \\
\text { False }\end{array}$ & $\begin{array}{r}18 \\
7 \\
9 \\
12\end{array}$ & $\begin{array}{r}13 \\
10 \\
9 \\
4\end{array}$ & $\begin{array}{l}67 \\
81 \\
80 \\
82\end{array}$ \\
\hline $\begin{array}{l}\text { Medicines that should be taken if the child is wheezy are*: } \\
\text { Antibiotics } \\
\text { Intal } \\
\text { Ventolin } \\
\text { Becotide } \\
\text { Bricanyl }\end{array}$ & $\begin{array}{l}\text { False } \\
\text { False } \\
\text { True } \\
\text { False } \\
\text { True }\end{array}$ & $\begin{array}{r}29 \\
6 \\
44 \\
6 \\
5\end{array}$ & $\begin{array}{r}11 \\
10 \\
2 \\
9 \\
9\end{array}$ & $\begin{array}{l}58 \\
82 \\
52 \\
83 \\
84\end{array}$ \\
\hline Ventolin is the best drug to take before games & True & 18 & 5 & 75 \\
\hline
\end{tabular}

${ }^{*}$ Becotide: beclomethasone dipropionate, Bricanyl: terbutaline, Intal: sodium cromoglycate, Ventolin: salbutamol.

Table 4 Responses of 98 teachers to questions about asthma and school

\begin{tabular}{|c|c|c|c|c|}
\hline & \multirow{2}{*}{$\begin{array}{l}\text { Correct } \\
\text { answer }\end{array}$} & \multicolumn{3}{|c|}{ Actual answers } \\
\hline & & Correct & Incorrect & Don't know \\
\hline \multirow{3}{*}{$\begin{array}{l}\text { Absence from school is a good indicator of severity } \\
\text { Having an attack at school can make a child more } \\
\text { apprehensive about asthma } \\
\text { Children with asthma are of similar intelligence to } \\
\text { other children }\end{array}$} & True & 44 & 36 & 18 \\
\hline & True & 66 & 14 & 18 \\
\hline & True & 84 & 11 & 3 \\
\hline
\end{tabular}

except those concerning the widely used bronchodilator Ventolin (salbutamol).

In the assessment of understanding about asthma and schoolchildren (table 4) most teachers believed correctly that asthmatic children are of similar intelligence to others. All the teachers thought that asthmatic children should be educated in normal schools.

Only $5 \%$ of teachers thought that they knew enough about asthmatic children (table 5), and only $4 \%$ reported that they had had any teaching or training about asthma. Eighteen per cent of teachers thought asthmatic children were different from other children, and 39\% said they would not allow asthmatic children to keep their inhalers with them. Sixty eight percent of teachers said they would supervise children when they were using their inhalers. Only a small proportion of teachers had had personal or family contact with asthma; $69 \%$, however, had taught asthmatic children.

An analysis was made of the possible effect of exposure to asthma (personal, relative, or child
Table 5 Responses of 98 teachers to questions about asthma and its management

\begin{tabular}{|c|c|c|}
\hline & Yes & No \\
\hline $\begin{array}{l}\text { Do you think you know enough about asthma in } \\
\text { children? }\end{array}$ & 5 & 93 \\
\hline $\begin{array}{l}\text { Have you ever had any training on the subject? } \\
\text { Have you noticed that asthmatic children are }\end{array}$ & 4 & 94 \\
\hline $\begin{array}{l}\text { different in any way? } \\
\text { Would you or do you allow asthmatic children }\end{array}$ & 18 & 80 \\
\hline $\begin{array}{l}\text { to keep their medicines with them? } \\
\text { Would you or do you supervise asthmatic children } \\
\text { using their inhalers? }\end{array}$ & $\begin{array}{l}53 \\
67\end{array}$ & 38 \\
\hline $\begin{array}{l}\text { Are you the parent of an asthmatic child? } \\
\text { If no, do you have any first degree relatives }\end{array}$ & $\begin{array}{r}0 \% \\
4\end{array}$ & \\
\hline $\begin{array}{l}\text { who are asthmatic? } \\
\text { Do you have, or have you ever had, asthma? } \\
\text { Do you have, or have you ever had an asthmatic }\end{array}$ & $\begin{array}{r}17 \\
6\end{array}$ & $\begin{array}{l}73 \\
92\end{array}$ \\
\hline $\begin{array}{l}\text { child in your class? } \\
\text { Have you ever had contact with the parents of }\end{array}$ & 68 & 3 \\
\hline $\begin{array}{l}\text { an asthmatic child in your class? } \\
\text { Is there a school nurse at the school? }\end{array}$ & $\begin{array}{l}57 \\
98\end{array}$ & \\
\hline
\end{tabular}

in the class) on knowledge and understanding by comparing groups with and without such experience. There was no significant difference between the two groups of teachers except on one statement (asthmatic children should be 
encouraged to participate fully in games; $\mathrm{p}<0.01)$. There were no significant differences between experienced and less experienced teachers (those with less than or greater than three years' teaching experience) except in their responses to the statement 'Ventolin helps fights chest infections', which more experienced teachers correctly marked as false.

\section{Discussion}

AMOUNT OF KNOWLEDGE

It is clear from this study that, in general, the teachers in this sample had limited knowledge and understanding of asthma andfurthermore-were aware of it. There are likely to be two or three children with asthma in any class of 25 children. Their management should benefit from optimal understanding of the condition, and of the care necessary for their well being. Our findings are similar to those of Storr et al, who found that the teachers that they studied were also aware of the paucity of their knowledge.

We found that teachers had particularly limited understanding of the treatment of asthma, and their knowledge of drugs such as sodium cromoglycate, beclomethasone dipropionate, and terbutaline was virtually nonexistent. Though one would not expect teachers to have extensive knowledge, it seems important that they should have some idea of which drug should be used when a child is wheezy and also that they should be aware of some of the side effects of the drugs used by children in their classes. Teachers are often responsible for supervising the giving of such drugs at school, and as asthma is such a common disorder all teachers should be able to do this effectively. It is quite likely that many asthmatic children are not receiving adequate medication while at school, be it therapeutic or prophylactic, and this is likely to have a deleterious effect on their overall health and confidence.

Teachers' understanding about asthma and sports and games was not ideal. Only $27 \%$ of teachers knew that playing games in a cold wind can provoke exacerbations of asthma, and only $34 \%$ knew that wheezing after exercise is highly suggestive of asthma. It is important that teachers are able to recognise when a child is becoming ill and also be aware of the stimuli that might trigger an asthmatic attack.

However, it is highly desirable that asthmatic children should be encouraged to take full part in school sports and activities, using the appropriate medication if necessary. Teachers are likely to feel more confident in their position of responsibility if they are able to discern when the child is becoming unwell and take what action is required. Several teachers in this study remarked on their lack of confidence on school trips, for example, when an asthmatic child became ill and there was no other help available, with resultant anxiety to both teacher and child.

The teachers performed rather better on the more psychosocial statements-for example, 'asthma is influenced by emotional factors' (true), 'asthmatic children commonly have overprotecive mothers' (false), and 'asthmatic children usually come from socially disadvantaged families' (false). This is likely to reflect the widespread belief, confirmed in this study, that asthmatic children are no different from other children and are no more likely to have protective mothers or come from socially disadvantaged backgrounds but, like other children, they may be influenced by emotional factors. All the teachers questioned believed that asthmatic children should be educated in normal schools. An appreciable proportion $(18 \%)$, however, believed that asthmatic children were different from other children. The reasons given included apprehension about children with asthma indulging in strenuous physical activity, lack of confidence, nervousness, and physical characteristics such as pigeon chest and eczema. This probably reflects the teachers' experience of individual children; an educational programme might provide a broader view.

\section{SCHOOL POLICY}

The arrangements for giving antiasthma medication in schools were generally unsatisfactory. Barely half the teachers would permit children to keep their inhalers with them, because of concerns about possible overdose, loss, use by other children, addiction, 'paranoia', and 'conflicts with school policy'. Individual comments suggested that some teachers believed children should be 'protected' from inhalers in case they developed an 'unhealthy attachment' to them. Most paediatricians, however, believe that children with diseases such as asthma, should take the responsibility for their own medication as soon as possible.

School policy on medicines varied considerably; often teachers were unaware of their own school's policy. One school forbade the use of medicines at school, and in the event of a child becoming ill he or she was either sent home or the mother had to bring the medicines to school. Such an arrangement is bound to cause disruption and unnecessary embarrassment to the child. In other schools a designated teacher was responsible for keeping the medicines, or they were kept in the office or headteacher's study. It is likely with such arrangements that children forego treatment and miss important prophylaxis.

\section{RECOMMENDATIONS}

Most of the teachers interviewed in the present study felt inadequate to cope with the responsibility of an asthmatic child. Colver reported a community campaign to increase knowledge and awareness about asthma among teachers, at the end of which almost all children were being allowed to keep their inhalers themselves, which led to improvement in school attendance and reduction in symptoms. ${ }^{5}$ Storr et al found that lectures about asthma for teachers were well attended, ${ }^{3}$ and Hill reported that since 1984 all teacher training courses at Warwick University have included a compulsory session on asthma with in service training for teachers being provided regularly. ${ }^{6}$ We recommend that 
all primary school teachers receive teaching about asthma during their teacher training courses, with regular in service training for those working in schools. This should include instruction about what stimuli can precipitate an acute asthmatic attack, standard antiasthma medication, and what to do if a child with asthma becomes unwell. Because a recent study showed that there was a lack of adequate knowledge about diabetes among some Birmingham school teachers, it may be desirable to include teaching on other chronic diseases. ${ }^{7}$ Schools should allow older asthmatic children to keep their inhalers with them so that children are encouraged to take responsibility for their own health care. Medication for young children (less than about 7 years of age) should be supervised by a responsible adult, preferably the class teacher. Such arrangments should minimise disruption to the child's life and lead to better management of asthma.

1 Lee DA, Winslow NR, Speight ANP, Hey EN. Prevalence and spectrum of asthma in childhood. $\mathrm{Br}$ Med $\mathcal{F}$ 1983;286: 1256-8.

2 US Department of Education and Welfare. US National Health Survey (1959-61). Illness among children. Washington, DC: US Department of Education and Welfare, 1963

3 Storr J, Barrell E, Lenney W. Asthma in primary schools. $\mathrm{Br}$ Med f 1987;295:251-2.

4 Hill RA, Britton JR, Tattersfield AE. Management of asthma in schools. Arch Dis Child 1987;62:414-5.

5 Colver AF. Community campaign against asthma. Arch Dis Child 1984;59:449-52.

6 Hill LS. Comment: asthma in schools. Respiratory Disease in Practice April/May 1988:5.

7 Warne J. Diabetes in school: a study of teachers' knowledge Warne J. Diabetes in school: a study of teachers' knowledge
and information sources. Practical Diabetes 1988;5:210-5. 